\title{
XXI a. viešojo valdymo modernizavimo reformų kryptys ir tendencijos
}

\author{
Alvydas Raipa \\ Mykolo Romerio universitetas \\ Ateities g. 20, 08303 Vilnius \\ DOI:10.13165/VPA-15-14-2-11
}

\begin{abstract}
Anotacija. Teoriniai-metodologiniai viešojo valdymo analizès, šiuolaikiniu modernaus valdymo kaitos, reformu ir pokyčiu globaliame pasaulyje tyrimai yra itin svarbūs šiuolaikiniu politiniu, administraciniu, socialiniu procesu sqveikos ir ryšiu tarp ju, integraciniu procesu pažinimo, interpretavimo kontekste, kai atsiranda naujos ryšiu ir squeikos tarp valstybès ir visuomenès valdymo instituciju ir piliečiu formos. Visa tai yra globalaus valdymo instituciniu struktūru, ju dinamikos, veiklos valdymo praktikos tobulinimo esminès indikacijos, nuo kuriu priklauso naujojo viešojo valdymo vystymosi tendencijos, modernizavimo iššūkiai ir naujų, pažangesniu ir inovatyvesniu valdymo formu isitvirtinimas, rengiant ir igyvendinant valstybès strategines nuostatas ir kryptis, ịvairiu lygiu viešąsias programas, sujungiant visu valstybès sektoriu, valdymo formu, struktüriniu dariniu ištekliu galimybes. Dangiausia dèmesio straipsnyje skiriama modernaus viešojo valdymo reformu sampratos, ju klasifikavimo pagal ịvairius indikatorius, vidinès ir išorinès organizaciju aplinkos faktoriu poveikio, reformu procesu sèkmès prielaidu, trukdžiu identifikavimui, viešojo valdymo reformu tendenciju prognostiniam eksplanavimui.
\end{abstract}

Raktažodžiai: viešojo valdymo reformos, valdymo reformos ideologija, modernizavimas, reformu modeliai, reformu tendencijos.

Keywords: public governance reform, ideology of governance reforms, modernization, models of reforms, tendencies of reforms.

\section{İvadas}

Analizuojant šiuolaikinio viešojo valdymo reformų praktiką ir patirtį, teoretikams iškyla nauji, sudètingi uždaviniai vertinant globalų reformų kontekstą, vals- 
tybės institucijų veiklos pertvarkas anglosaksiškose viešojo valdymo sistemose, suvokiant reformų turinį ir kryptis Pietų Europos valstybèse bei Vidurio ir Rytų Europos erdvėje. Viešojo valdymo procesų kaitos tyrinėtojams privalu suvokti ne tik reformų atskiruose regionuose ir šalyse kontekstą, bet ir gebėti konceptualizuoti tradicinio administravimo metodologinių vertybių reikšmę formuojantis naujiems viešojo valdymo reformų modelių konstruktams. Todèl viešojo valdymo reformų generalizavimas tampa inkrementiško pobūdžio būtinybe. Tokia permanentinè viešojo valdymo reformų eiga, jos analizės procesinè-sisteminė prieiga leidžia geriau ịvertinti Europos Sajungos ir kitų regionų bei valstybių bendrąją patirtị modernizuojant valdymo procesus, geriau suprasti ir išskirti reformų specifiką, trajektorijas nacionaliniame ir subnacionaliniame lygmenyse. Kompleksinè metodologinè tyrimų orientacija valdymo procesų praktikos tyrinètojams sudaro galimybes plačiau panaudoti mišrios analitinès sintezès, klasifikavimo, vertinimo, prognostinius tyrimo instrumentarijus identifikuojant valdymo procesų reformų turinị, dinamiką, išryškejjusias naujas valdymo formų ir metodų reformavimo tendencijas bei reikalingas jų reinventorizavimo ir tikslingas jų reorientacijos kryptis. Todèl straipsnyje, taikant teorinio modeliavimo, analitinès sintezès, metaanalizès, klasifikavimo, interpretavimo ir prognostinius metodus, keliamas tikslas - identifikuoti ir eksplanuoti modernaus viešojo valdymo reformų etapo ypatumus, viešojo valdymo reformų prielaidas ir sėkmès faktorius bei pabandyti išskirti ir apibendrinti galimas viešojo valdymo sistemų reformų kaip modernizavimo instrumentų kryptis ir tendencijas.

\section{Viešojo valdymo reformų samprata}

Viešojo valdymo reformų samprata dažniausiai siejama su valdymo struktūrų, jų veiklos procesų bei atliekamų (deleguotų, priskirtų) funkcijų pokyčiais socialinių, ekonominių, politinių, kultūrinių ir ideologinių vertybių srityje. Šiuolaikiniame viešojo valdymo etape modernizavimo reformų strateginių krypčių ir tikslų identifikavimas tampa esmine sąlyga viešojo sektoriaus veiklos valdymo efektyvumui didinti, geriau koordinuoti viešųjų institucijų pastangas siekiant jų veiklos produktyvumo valdant visų rūšių organizacinius išteklius, keičiant organizacinę elgseną, sprendžiant valstybinio reguliavimo ir demokratinio valdymo plètros derinimo problemas, priimant ir igyvendinant sprendimus, sukuriant viešąą vertę kaip visų valstybėje egzistuojančiu sektorių (viešojo, privataus ir nevyriausybinio) kryptingu pastangų rezultatą [14, p. 223-229].

XXI a. viešojo valdymo modernizavimo reformų metodologinis pagrindimas, teorinio modeliavimo ir praktikos paieškos formuojasi ir vystosi kartu su atsinaujinančiomis tradicinėmis viešojo valdymo veiklos formomis ir institutais. Kartu turime ịvertinti radikalų viešojo valdymo sistemų, jų funkcijų, veiklos procesų reformų pobūdị XX-XXI a. sandūroje, kai esminèmis valdymo modernizavimo dominantėmis tampa nauji iššūkiai formuojant inovacines valdymo reformų trajektorijas ir 
kryptis viešosios politikos formavimo strateginių sprendimų, programų ir projektų valdyme, siekiant viešųjų paslaugų teikimo efektyvumo augimo [20, p. 3-4].

Reformuojant viešojo sektoriaus valdymą XX a. pabaigoje imta vartoti terminą „,viešosios vadybos“ reformos, suprantamą kaip inovatyvią viešojo valdymo ideologiją ir praktiką, siejamą visų pirma su pokyčiais valstybès ir verslo santykiuose. Toks viešojo sektoriaus reformų orientyras gana sparčiai ima keisti tradicinio vèberinio-vilsoninio administravimo principus ne tik permanentinio evoliucionavimo, bet ir radikalių, valstybinio reguliavimo reformų realizavimoịrankiais, metodais, procedūromis, kurių ideologiniu pagrindu buvo ịvairiarūšès, liberalizmo pagrindu susiformavusios politinès doktrinos interpretacijos ir požiūriai ị piliečių dalyvavimą valdyme, teisinius valstybinio reguliavimo imperatyvus, viešojo sektoriaus organizacijų veiklos racionalumo, efektyvumo, produktyvumo, strateginio valdymo vietą ir reikšmę viešosios vertès kūrimo procese. Todèl darytina išvada, kad valdymo reformų proceso tobulinimas valstybiniame reguliavime, kaip vienoje iš svarbiausių viešojo valdymo subsistemų, yra itin svarbus determinantas viešosios vadybos paradigmos struktūroje $[13$, p. 2].

Viešojo valdymo reformų analizė leidžia apibendrinti ịvairią valdymo modernizavimo reformų patirtị, ịvertinti naujosios viešosios vadybos vietą, vaidmenị ir rezultatus lyginamosios analizės metodais ir siekti apibendrintą patirtị efektyviau naudoti viešųjų organizacijų veikloje.

Tai yra neįmanoma vadovaujantis vien tik mechanistiniu požiūriu, t. y. siekiant perkelti arba aklai kopijuoti atskirų valdymo sistemų veiklos praktikas. Tokias valdymo reformavimo metodologines nuostatas itin svarbu priimti tarptautinėms, asocijuotoms, viešojo valdymo reformas koordinuojančioms struktūroms, valdymo reformavimo konsultacinèms institucijoms, kurių esminė funkcinè paskirtis - formuoti bei skatinti bendriausių reformų ideologinių nuostatų, konstruktų rengimą ir praktikos plètrą, tobulinti ịvairias administracinių sistemų, egzistuojančių pasaulio regionuose, konvergencijos formas, suvokiant valdymo modernizavimo reformas tiek kaip atskiras doktrinas, tiek kaip valdymo paradigmas pačia plačiausia prasme - kaip valstybės politinių, socialinių, ekonominių, ideologinių procesų visuminių reikšmių reformavimo fundamentą. Toks viešojo valdymo reformų konceptualizavimas reiškia naujų metodologinių tyrimo prieigų formavimą, leidžiantị išskirti ịvairias valdymo reformų prielaidų, sąlygų, jų eigos ir efektyvumo dimensijų specifikas, geriau identifikuoti ir aiškiau eksplanuoti tradicinių valdymo vertybių ir bendrųjų valdymo sistemų modernizavimo XX-XXI a. sandūroje sąveiką, t. y. skirtingų reformų turinio, formos ir konteksto požymių koegzistencijos procesų charakteristikas.

Viešojo valdymo reformos nėra specifinis šiuolaikinio valdymo etapo bruožas. Jis būdingas visoms viešojo valdymo stadijoms ir ciklams. Ch. Pollittas ir G. Bouckaertas (2003) išskiria tris viešojo valdymo reformų etapus:

- Pirmas etapas apibūdinamas kaip tradicinis vėberinis-vilsoninis modelis, kai dominuojantys yra biurokratinis valdymas ir hierarchinio valdymo konstrukcijos; 
- Antrasis valdymo reformų etapas pasižymi įvairių interesų grupių, dalyvių įtraukimu ị valdymo sprendimų rengimą, viešųjų paslaugų teikimą, privačių struktūrų ir pilietinès visuomenès organizacijų platesnị dalyvavimą, rinkos mechanizmų vaidmens augimą.

- Trečiame etape dominuojančia trajektorija igyvendinant valdymo reformas tampa horizontalioji integracija, ženkliai papildanti hierarchinę ir rinkos integraciją, siekiant išvengti pernelyg stiprių valstybinio valdymo fragmentacijos tendencijų pavojų [15, p. 89, 311-312].

Rytų ir Vidurio Europos regionai viešojo valdymo reformas pradèjo ne nuo tradicinio vẻberinio-vilsoninio modelio, bet nuo priešvėberinių valdymo modelių, t. y. nuo vadinamosios ,valstybès - partijos ir partijos - valstybès“ sistemos. Esminiai pokyčiai šiuose regionuose prasidèjo nuo valstybės funkcijų reformavimo bandymų. Tai dar 1992 m. apibūdino daugelis teoretikų, lygindami vakarietiškų valstybių funkcionavimo ir reformų kaitą bei Rytų bei Vidurio Europos valstybių funkcijas prieš transformacijas ir potransformacineje aplinkoje.

\section{1 lentele. Valstybių funkcijų kaita [10, p. 45-46]}

Vakarietiškos valstybės funkcijos

\begin{tabular}{|c|c|}
\hline Prieš transformacijas & Po transformacijų \\
\hline Ekonominis organizavimas & Teisinių nuostatų įtvirtinimas \\
\hline Kultūrinè-edukacinè & Mažiau akcentuota ideologija \\
\hline Visuomenès integracija & Pilietinès visuomenės vaidmens augimas \\
\hline
\end{tabular}

Rytų ir Vidurio Europos valstybių funkcijos

\begin{tabular}{|c|c|}
\hline Prieš transformacijas & Po transformacijų \\
\hline „Etatistiniai“ irankiai & Socialiniai ir rinkos mechanizmai \\
\hline Politiškai ir ideologiškai lojalus personalas & Valstybės tarnybos parengimas \\
\hline Demokratinis centralizmas & $\begin{array}{c}\text { Valdžios išskirstymas i horizontalias ir } \\
\text { vertikalias trajektorijas }\end{array}$ \\
\hline Partiniai sprendimai & Teisinis ir ekonominis reguliavimas \\
\hline
\end{tabular}

Analizuojant valdymo reformų procesų turinị galima teigti, kad kvalifikuojant reformų valdymą ir jos trajektorijų prognozavimą yra tikslinga vartoti „,modernizavimo" definiciją, kadangi pokyčių terminas ne visada adekvatus ir galimas derinti su valdymo reformos terminų interpretacijomis. Ypač tai aktualu, kai susiduriame su pozityvių pokyčių eksplanavimo ir vertinimo tendencijomis [13, p. 5].

Modernizavimo reformų procesas pasižymi reformų strategijų, krypčių, igyvendinimo mechanizmų ịvairove. Tai lemia įvairūs požiūriai, reformų valdymo konceptualizavimo metodologinis lygmuo, reformų tikslingumo atskiruose regionuose ir sferose kontekstas. Tačiau reformų, kaip modernizavimo proceso, struktūrą gali- 
ma determinuoti kaip visumą ciklų, tokių kaip: reformų būtinumo ir reformavimo kaip inovatyvios veiklos suvokimas; reformų kaip modernizavimo mechanizmo esminès dedamosios institucionalizavimas ir politinès paramos užsitikrinimas; reformų metu išryškèjusių disfunkcijų, trukdžių ir kontrapreneriškų tendencijų organizacijų veikloje išeliminavimas [8, p. 309-311]. Toks cikliškas valdymo reformu pobūdis leidžia užtikrinti didesnị organizacijos vidinių darinių funkcijų, atsakomybės sferų pasiskirstymo balansą, būtiną kompleksiniam valdymui modernizuoti kaip darnios organizacijų veiklos konstruktų praktiniam realizavimui užtikrinti, tarpsektorinei integracijai įtvirtinti reformavimo procese [7, p. 3].

\section{Viešojo valdymo reformų organizacinès prielaidos}

Valdymo reformų ịvairovė priklauso nuo daugybės faktorių. Vienas iš svarbiausių yra administravimo tradicijos, kurios suprantamos kaip istoriškai susiklosčiusių vertybių (struktūrų organizavimo, veiklos formų patirtys, t. y. administravimo institucinès veiklos darinių tarpusavio sąveikos, specifinių viešojo valdymo bruožų) visuma, jungianti valstybès ir visuomenės, politikų ir administratorių sąveiką, atsakomybės suvokimą, t. y. tokị palikimą, kuris tiesiogiai ir netiesiogiai yra itin svarbus ir darantis poveikị viešojo valdymo reformų turiniui. Kartu reikia pabrèžti, kad administravimo tradicijos nèra statiškos. Jos dinamiškai transformuojasi kartu su globalizacijos iššūkių suponuotais pokyčiais, veiklos valdymo modernizavimu, inovatyvios administracijos struktūrų praktikos diegimo pozityvia patirtimi, kontrapreneriškomis nuostatomis ir trukdžiais, t. y. su organizacinių reformų rengimo ir igyvendinimo kultūros (plačiąją prasme) transformacijomis [13, p. 7].

Žymus danų organizacijų teorijų specialistas G. Hofstede'as organizacinę kultūrą apibūdina kaip didelès arba didesnès kultūros sistemos subkultūrą. Reikia pabrèžti, kad mūsų nagrinėjamu aspektu G. Hofstede’o tyrimai ir darbai aktualūs dèl to, kad jis ne tik identifikavo specifinius, išmatuojamus kultūrinių dimensijų skirtumus, bet ir susistemino teorinius teiginius, kad organizacinė kultūra yra būdas ir priemonè, kuriais visuomenei daromas poveikis, t. y. nacionalinè kultūra yra tarsi skirtingų organizacijų kultūrų visuma arba kontekstas [8, p. 185].

Organizacijų teorijos specialistai dažniausiai diskutuoja, kiek ir kaip įmanoma pakeisti ir paveikti organizacinę kultūrą, t. y. modeliuoti ir nustatyti vadybos mokslo galimybes padedant veikti organizacinę kultūrą, organizacinę elgseną, institucines normas ir vertybes, t. y. formuoti vadinamąji organizacinès kultūros dizainą naudojant valdymo reformavimo mechanizmus ir taip siekiant ịvairių organizacijų veiklos reikšmių pokyčių. Kiti teoretikai teigia, kad galimybės keisti organizacinę kultūrą kaip bendrosios kultūros subkultūrą yra gana ribotos, nes reformų procese organizacinè kultūra ir bandymai ją keisti dažnai turi daug konformizmo, spekuliatyvinių elementų, pacifistinių nuostatų, kurių nereikia painioti su organizacijų gebejjimais lanksčiai veikti prisitaikant prie objektyvių pokyčių, netgi veikiant (spartinant ar pristabdant) juos santykinai subjektyviai. Tačiau įvairių pozicijų 
besilaikantys organizacijų kultūros tyrinètojai sutinka, kad organizacijų lyderiai, aukščiausio lygmens vadybininkai labiausiai daro ịtaką organizaciniams valdymo reformų kultūros pokyčiams [8, p. 206-207].

Žinomi viešojo valdymo tyrinètojai T. Bovairdas ir E. Loffleris organizaciju reformoms poveikị darančius išorinès aplinkos faktorius skirsto į:

- Politinius (naujų socialinių-politinių judèjimų atsiradimas, piliečiu lūkesčių pokyčiai tikintis kokybiškesnių viešųjų paslaugų teikimo, informacijos priemonių galimybių plètra, pasitikèjimo partijomis, valdymo elito gebejjimais efektyviai spręsti iškylančias visuomenès problemas trūkumas, jų atsakomybès bei atskaitomybès stoka).

- Ekonominius (siejamus su piliečių gerovès, jų pajamų augimu, mokesčių reguliavimo problemomis, siekiant teisingesnių mokesčiu sistemų įtvirtinimo. Ekonominių reformų kontekste itin svarbūs tampa piliečių poreikių realizavimas konsoliduojant profesinių sąjungų kaip darbo rinkos ir darbo santykių dalyvių vaidmeni).

- Socialinius (siejamus su socialinès sferos, t. y. paslaugų, nedarbo politikos ir užimtumo skatinimo, individų teisių ị saviraišką, savireguliacijos procesų ịtvirtinimą, minimalaus gyvenimo lygio parametrų augimą, reikšmingą socialinès atskirties grupėms, rasinès, socialinès, lytinės diskriminacijos išeliminavimą ir vaikų teisių apsaugą, naują darbo santykių kokybę ir kt.).

- Technologinius (susijusius su technologiniais pokyčiais, siekiant inovacinių technologijų ir sprendimų taikymo ir realizavimo kasdienėje valdymo procesų aplinkoje).

- Aplinkosauginius (siejamus su klimato pokyčiais, naujų alternatyvių energijos šaltinių paieška ir panaudojimu, atliekų utilizavimo procesų sudètingumo ir visuomenès aktyviu spaudimu siekiant tiesiogiai dalyvauti sprendžiant ekologinesenergetines XXI a. problemas).

- Teisinius (siejamus su pasaulinių institucijų - Jungtinių Tautų, Pasaulio banko, Pasaulio prekybos organizacijos ir kt. veikla formuojant naujas teisines valdymo reformų realizavimo užduotis ir standartus nacionalinėms valstybėms. Kartu teisiniai viešojo valdymo reformų faktoriai skatina žymiai aktyvesnį pilietinès visuomenès dalyvavimą valstybės institucijų veiklos teisinès priežiūros procesuose [4, p. 16-18].

Itin svarbia viešojo valdymo reformavimo prielaida ir stimulu tapo $2007 \mathrm{~m}$. ekonomikos ir finansų krizè, prasidejusi JAV ir išplitusi ị Europos bei Azijos šalis, kuriose negatyvūs padariniai skatino ir tebeskatina ieškoti netradicinių viešųjų išteklių (visų pirma finansinių) valdymo sprendimų. Krizei užsitęsus, valstybės institucijos ịvairiuose regionuose ieškojo būdų ir priemonių, kaip geriau reguliuoti valstybẻs biudžetų, strateginių programų valdymą rinkos ekonomikos sąlygomis. Daugelyje JAV ir Europos šalių valstybės finansinès institucijos tiesiogiai sustiprino finansinę privačiu bankų priežiūrą ir valstybès reguliavimo lygmenị gelbėjant bankininkystės verslą nuo bankroto grèsmès. Stiprinant teikiamų finansinių paslaugų saugumą ir užtikrinant visuomenès poreikius, valstybès taikè įvairias ban- 
kų restruktūrizacijos formas ir kitas jų veiklos pertvarkos priemones, netgi bankų perèmimą valstybės nuosavybèn. Taip buvo stiprinama valstybės vaidmuo ir atsakomybė. Valstybè tokiomis būtinomis priemonėmis reformavo institucijų veiklą ir tam tikra prasme susigrąžino dalị valstybès valdymo funkcijų, kurios naujosios viešosios vadybos reformų metu $\mathrm{XX}$ a. pabaigoje, vyraujant privatizacijos, viešojo sektoriaus struktūrų ir funkcijų bei valstybinio reguliavimo hipertrofuoto segmentavimo aplinkai buvo perduotos ịvairių lygių verslo struktūroms bei vadinamosioms nepriklausomoms agentūroms [17, p. 131-132].

Žinoma, toks valstybès reguliavimo stiprinimas iš dalies kvestionavo esminius naujosios viešosios vadybos ideologinius postulatus, susijusius su verslo valdymo principų institucionalizavimu viešojo valdymo struktūrineje-funkcinejje erdvèje. Tačiau galima teigti, kad 2007-2010 m. krizès pamokos suponavo nauju viešojo valdymo reformavimo tendencijų atsiradimą. Antai, vyraujanti viešojo ir privataus sektorių partnerystės doktrina ir partnerystės praktika, sustiprinus valstybès institucijų poveikį, priežiūrą, kontrolę, teisines įstatymų procedūras, ima transformuotis ị naujas, aukštesnes tarpsektorinès partnerystès formas, apibūdinamas kaip tarpsektorinè integracija. Tinklaveikos, integracinių procesų efektyvumas reformų procese priklauso nuo socialinių mechanizmų, garantuojančių vadinamųjų „santykių“, arba struktūrinės sąveikos, îtvirtinimą. Santykiai tinklaveikoje daugiau determinuoja tinklų dalyvių dvipusius ryšius, o struktūrinio pobūdžio įtvirtinimas peržengia tinklinių dvipusių santykių konceptą ir suprantamas kaip trečiųjų dalyvių ịtraukimas, leidžiantis trikampio modelio tinklų jungtyse užtikrinti efektyvesnị tinklų valdymą, kaip šiuolaikinio viešojo valdymo modernizavimo reformų strategijų esmines kryptis [12, p. 446-449]. Valdymo teoretikai skiria trijų ryšių: politikos, bendradarbiavimo ir valdymo tinklų formas, nuo kurių labiausiai priklauso reformų sèkmè. Pirmoji tinklų forma daugiau atspindi valstybinių institucijų ir valdymo organizacijų junginių veiklą valdant sprendimų rengimo ir igyvendinimo procesus. Antroji - bendradarbiavimo tinklai orientuoti ị tarpsektorinę sąveiką, apimant visus tris sektorius ir dalijantis funkcijomis, būtinomis teikiant viešąsias paslaugas. Valdymo tinklai apima politikos formavimo ir igyvendinimo procesus koordinuojant tinklaveikos sistemų veiklą kuriant viešąją vertę [9, p. 163-166].

Dominuojančiomis trapsektorinès sąveikos trajektorijomis tampa ne dviejų sektorių (viešojo ir privataus) kontraktų mechanizmų valdymas, o spartus tinklaveikos procesų ir mišrių - hibridinių struktūrų (formalių ir neformalių) gausèjimas. Koordinuojančios funkcijos, strateginių prioritetų, priežiūros ir kontrolès funkcijos tampa valstybès institucijų veiklos reformavimo prioritetais [1, p. 123-128].

Tokios viešojo valdymo reformos davė pradžią neovėberizmo doktrinos kaip viešojo valdymo institucinès veiklos XXI a. pradžioje įvardijimui, nors patị terminą ,neovėberizmas“ kaip vieną iš gerojo valdymo reikšmių mini žymus valdymo teoretikas V. Ostromas dar 1989 m. Neovėberiškas viešojo valdymo stilius dažnai yra interpretuojamas kaip valdymo hibridinio evoliucionavimo modelis, jungiantis naujosios viešosios vadybos paradigmos racionalų grūdą bei tam tikrus vektorius i 
valdymo sistemų pokyčius, būdingus vadinamojo „tranzitinio“ valdymo formoms, kai dažnai negalima determinuoti vienam ar kitam valdymo etapui, paradigmai ar doktrinai būdingų valdymo sistemos konstrukcijų, formų ir kt. Išsamiau aptariant tokias valdymo reformų aplinkybes, hibridines valdymo formas, reikia pabrèžti valdymo sistemų kaitos ir veiklos normatyvinio reglamentavimo, tarnautojų kompetencijos, naujų kontrolès ir atsakomybės formų atsiradimo svarbą, demokratinio valdymo institucijų poveikio galimybių plètojimą, ekspertų ir ekspertizių bei piliečiu asociacijų dalyvavimo reikšmę [16, p. 39-43].)

$\mathrm{XX}$ a. aštuntojo dešimtmečio pabaigoje prasidèję viešojo valdymo reformavimo procesai igauna vis dinamiškesnes reikšmes, tampa savotišku fenomenu, jungiančiu itin sudètingų globalaus valdymo procesų prielaidų, determinantų, indikatorių, poveikio visuomeninių reiškinių kaitai holistines - visumines charakteristikas. Itin dinamišką pobūdị viešojo valdymo reformos dẻl daugelio aplinkybių (socialinių, ekonominių, technologinių pokyčių, viešųjų paslaugų proceso kaitos, politinès sistemos ir valstybės tarnybos, kaip viešojo administravimo subsistemu transformacijų) sparčiausiai buvo siekiamos igyvendinti anglosaksiškos viešojo valdymo tradicijos aplinkose, kur spartejjantys pokyčiai greičiau generavo viešojo valdymo reformų ideologijos atsinaujinimo, naujų viešojo sektoriaus vadybos paradigmų formavimo užduotis, politikos ir administravimo dichotomijos, viešojo ir privataus sektoriaus sąveikos, demokratinio valdymo tobulinimo, naujų inovatyvių valdymo procesų modelių, mechanizmų konstrukcijų, metodų ir procedūrų kūrimo reformų dalyviams - viešosios politikos formuotojams, strateginių jos krypčių, programų igyvendinimo administracijai.

Naujų viešojo valdymo reformų ideologinių nuostatų formavimui XX a. pabaigoje - XXI a. pradžioje turejjo įtakos itin aktyvūs mokslininkų, valdymo praktikų debatai, diskusijos, argumentai, ịvairiausių teorinių prielaidų ir interpretacijų, veiklos modeliavimo požiūrių visuma kaip terpè vis gilesniam naujosios viešosios vadybos vaidmens supratimui, jos sąveikos galimybių su kitomis globaliomis valstybès valdymo reformų paradigmos atmainomis, tokiomis kaip „naujasis viešasis valdymas", „geras“ valdymas, „sumanus“ valdymas ir itin „kultivuojama“ kontinentineje Europoje „neovéberinio valdymo“ ir „neovéberinès valstybès“ kaip XXI a. valdymo reformų ideologija ir praktika [13, p. 2]

Itin reikšmingos sąlygos, prielaidos ir aplinkybès modernizuojant ir reformuojant šiuolaikinį viešąji valdymą yra valstybinio valdymo sistemų (biurokratinio organizavimo struktūrų ir jų atliekamų funkcijų) kaitos planavimas, reformas vykdančių struktūrų formavimas, organizacijų pasirengimas reformoms ir kt. XXI a. viešojo valdymo sistemų negalima ịsivaizduoti be efektyvios jų veiklos planuojant ir ịgyvendinant organizacijų veiklą, rengiant ir ịgyvendinant sprendimus, susijusius su efektyvumo ir kokybės kaip esminio reformavimo vektoriaus akcentavimu vykdant viešojo valdymo modernizavimo reformas. 


\section{Viešojo valdymo reformų tendencijos}

Modeliuojant viešojo valdymo modernizavimo reformų kryptis ir perspektyvas, prognozuojant galimas reformų pasekmes J. E. Lane skiria nemažai šiuolaikinio viešojo valdymo etapui būtinų teorinių nuostatų, galinčių padèti suprasti ir ịvaldyti reformų metodologini instrumentarijų, t. y. gebejjimus suvokti viešojo valdymo modernizavimo reformų logiką kaip visuminị - sisteminị organizacinès elgsenos, organizacinès kultūros, veiklos vadybos - derinị. Kaip tokios teorijos gali būti ịvardijama biurokratinio valdymo reformų modeliavimas, kaip postbiurokratinių sistemų veiklos, kontrolès ir vertinimo dirbtinès realybės rekonstrukcijos visuma. Kita, reformų metodologijai būdinga teorinio diskurso sritis yra modernizavimo, reformų vietos ir vaidmens viešojo sektoriaus veiklos efektyvumo struktūroje apibrèžtis. Trečią šiuolaikinio valdymo reformų metodologinio instrumentarijaus tobulinimo kryptị atspindi inovatyvumo ideologijos ir inovatyvumo praktikos problemų identifikavimas kaip XXI a. valdymo reformų indikatorių išskyrimo esminės reikšmės. Ir ketvirta teorijų grupé, reikšminga reformų procesų rezultatų kokybiniams parametrams, yra siejama su ịvairiomis demokratinio valdymo, piliečių dalyvavimo, institucijų socialinės-korporatyvinès atsakomybės stiprinimo formų modeliavimu [11, p. 13-22, 65-67, 102-103].

Formuojant viešojo valdymo reformų perspektyvas turime identifikuoti svarbiausias šiuolaikinių valdymo procesų kaitos, kaip labiau subjektyvaus faktoriaus, galinčio pozityviai paveikti reformų rezultatus, aplinkybes ir dedamąsias, tokias kaip: globalų reformų pobūdị, reformų būtinumą, naujas valdžios institucijų ir visuomenès santykių kokybines charakteristikas, teorines konstrukcijas ir interpretacijas (kaip išimtinai subjektyvios veiklos rezultatą), metodologinio instrumentarijaus valstybės institucijų veiklos reformavimui būtinumą. Tokią šiuolaikinio valdymo kaitą reprezentuojančių reformų visumą geriausiai charakterizuoja subjektyvaus ir objektyvaus pobūdžio evoliucinè, transformacinè naujosios viešosios vadybos tąsa link naujojo viešojo valdymo. Tokios metavaldymo formavimosi tendencijos negali atsirasti be naujų, reformas formuojančių ir ịgyvendinančių formalių ir neformalių institucijų, kurių veikla nukreipta ị integracinių tinklaveikos procesų plètrą, naujų alternatyvių postbiurokratinių ir kontrolès formų sukūrimą, viešojo valdymo struktūrų veiklos koordinavimo ir atsakomybès funkcijų tobulinimą [16, p. 39-41].

Šiuolaikinio viešojo valdymo reformų analizè rodo, kad valdymo reformų turinį, jų efektyvumą, produktyvumą pirmiausia lemia sisteminiai politinès, ekonominès, socialinės ir kitų viešojo gyvenimo erdvių ir reikšmių pokyčiai. Kartu reikia pabrēžti, kad ịvertinti viešojo valdymo reformų rezultatus ir išmatuoti jų poveikị ịvairioms viešųjų organizacijų veiklos vadybos charakteristikoms, visuomenès reikmių ir interesų grupių lūkesčių tenkinimo kokybei, yra itin nelengva. Viešojo valdymo demokratizavimo reformų tikslai yra sufokusuoti į valdymo procesų efektyvumo ir kitų kokybinių veiklos parametrų ịtvirtinimą, jų suderinimą su viešojo valdymo sisteminių reformų demokratiniu kontekstu. Teoretikai, plètodami 
valdymo efektyvumo ir reformų demokratizavimo trajektorijas, siekia pagrịsti šios, nelengvai igyvendinamos ir sunkiai vertinamos sąveikos veiksnius ir faktorius. Svarbiausios šios sąveikos problemiškumo reikšmès yra tradicinio viešojo valdymo kaip biurokratinio valdymo interpretavimas, kuris dažnai vertinamas kaip antagonistinis valdymo demokratinių procesų tendencijų stiprèjimui. Todẻl svarbios dimensijos vertinant biurokratinio valdymo ir valdymo demokratizavimo procesu sąveiką yra siekiai išskirti svarbiausius veiksnius, faktorius, galinčius pozityviai paveikti tradicinio valdymo ir reformavimo tendencijų dualizmą. Kaip tokie veiksniai ir faktoriai dažniausiai išskiriami tiek vidinès, tiek išorinès organizacijų aplinkos ypatumai, valdymo sistemų ir struktūrų išteklių, galimybių ribų nustatymas, organizacijų vadovų ir personalo gebéjimai tobulinant sprendimų priėmimą ir igyvendinimą, jų patirtys valdant nuolat kylančius konfliktus, įveikiant trukdžius. Tam būtinas modernių teisinių - norminių ịrankių funkcionavimo užtikrinimas visuose valdymo reformų lygmenyse, piliečiu , asocijuotų struktūrų dalyvavimo realus įtvirtinimas, modernios veiklos vadybos formų, metodų, procedūrų ir kitų sisteminiųprocesinių veiklų iggyvendinimas [6, p. 669-673].

Tokị vertinimo sudètingumą lemia ịvairūs faktoriai, tokie kaip: pokyčių sisteminis pobūdis, viešųjų paslaugų teikimo kokybès standartai, organizacijų veiklos vadybos formų ịvairovè, strateginių uždavinių formavimo ir ịgyvendinimo klaidos ir procesų eigos trukdžiai. Institucinès veiklos kūrybingumą ribojanti biurokratinio mąstymo ir veiklos rutina, planuojant ir realizuojant visų rūšių išteklių valdymą dažnai tampa reikšmingais faktoriais igyvendinant planuotus reformų politikos uždavinius. Tokiais atvejais viešojo valdymo reformų rezultatyvumą lemia tiek reformų politikos formavimo, tiek reformų politikos igyvendinimo kaip valdymo proceso fazių ir procedūrų sąveika [18, p. 16-21]. Todèl vertinant reformų efektyvumą būtina atkreipti dèmesị ị politikos formuotojų ir administracinių struktūrų gebèjimus, esamas galimybes, organizacijų išorinės aplinkos faktorius bei organizacijų personalo kokybinius parametrus, kurie nulemia planavimo, finansų valdymo, veiklos monitoringo, audito ir vertinimo modernizavimą, inovacinès valdymo reformų ideologijos ir jos praktinio realizavimo rezultatyvumą, visų pirma, sprendimų rengimo ir jų iggyvendinimo tiek valstybès strateginių, tiek sektorinių reformų lygmenyse [5, p. 18-19].

Šiandienos teoretikų požiūris ir organizacijų valdymo praktika aiškiai demonstruoja vis dar gajų tradicinio viešojo valdymo, t. y. biurokratinių formų valdymo, poveikį. Toks biurokratinio organizacijų valdymo modelis XX a. įvairių valstybių organizavimo formų arsenale reiškè, visų pirma, labai griežtas institucinių darinių veiklos ir jų atsakomybès formas bei funkcines alokacijas, manant, kad toks viešojo sektoriaus struktūrų organizacinès veiklos formalizavimas yra pajègus spręsti ir užtikrinti tinkamus institucinès veiklos efektyvumo, produktyvumo ir kokybės parametrus. Tačiau XX a. antroje pusėje organizacijų veikos formos, principai, standartai, atrodę nepajudinami ir pozicionuojantys klasikinius organizacijų ir veiklos vadybos bruožus, iggauna gana spartų transformacinį pagrindą, kurio 
esminiais determinantais tampa siekiai keisti formalių klasikinių biurokratinių organizacijų veiklos stilių, reformuoti organizacinių strateginių krypčių formavimo ir igyvendinimo metodus ir instrumentus, išeliminuoti atsiradusias veiklos disfunkcijas. Valdymo teoretikai, vertindami formalios biurokratinès organizacijos veiklos modelius, identifikuoja tokias jų silpnybes:

- Formalių organizacijų elgsena dažnai nèra reali jų elgsena, nes organizacijų veiklos praktika ir rezultatai gali labai stipriai skirtis nuo pradinių organizacijos intencijų ir tikslų.

- Kartu formalių organizacijų vidinejje aplinkoje vystosi neformalios struktūros, galinčios vienaip ar kitaip paveikti formalios organizacijos veikos rodiklius, stimuliuoti arba priešintis veiklos reformoms.

- Formalios organizacijos dažniausiai naudoja kietas, griežtas priemones ir technologijas siekiant organizacinių tikslų, o tai dažnai turi kontrproduktyvų pobūdị.

- Organizacijų vadovybe, vadovaujantis personalas ne visada yra labiau kvalifikuotas nei tiesioginiai organizacijos strateginių uždavinių igyvendintojai - praktikai, turintys ilgalaikę veiklos patirtị, geriau besiorientuojantys organizacijų veiklos perspektyvų ir uždavinių formavimo ir igyvendinimo praktikoje.

- Nors formalios organizacijos negali nepriimti globalių iššūkių ir stabdyti būtinų pokyčių, priešintis modernizavimo reformoms, tačiau tai nereiškia, kad formalios organizacijos visada automatiškai rems inovatyvios aplinkos formavimą, būtiną sėkmingam reformų vykdymui [11, p. 13].

Visos viešojo valdymo teoretikų ir praktikų pastangos konstruojant valdymo reformų ideologiją, jos ịgyvendinimo metodologijas ir praktinio jų realizavimo mechanizmus buvo ir yra orientuotos didinti valdymo efektyvumą ir produktyvumą, t. y. siektipagerinti kiekybinius ir kokybinius viešųjų struktūrų veiklos rodiklius, pasitelkiant inovatyvias veiklos procesų reorganizavimo technologijas [2, p. 74]. Didžiausias dėmesys yra sutelkiamas ị valdymo personalo gebėjimų ugdymą, informacinès sklaidos užtikrinimą, paslaugų teikèjų ir vartotojų - klientų sąveikos būtinumą ne tik užtikrinant grị̌tamąji ryšị, bet ir ženkliai išplečiant klientų kaip vartotojų dalyvavimą viešujų produktų, paslaugų bendrakūrimo procese. Tai galima pasiekti užtikrinant sistemingus vartotojų - klientų poreikių ir lūkesčių tyrimus, klientų pateikiamų alternatyvių sprendimų analizę, tinklaveikinių, integracinių procesų visumos bei veiklos procesų vertinimo tobulinimą [19, p. 81-82].

Viešojo valdymo reformų tyrinètojai sutinka, kad kartu su ,naujosios viešosios vadybos" paradigma prasidejusi šiuolaikinè valdymo reformų generacija praktikoje buvo gana sėkminga XX a. pabaigoje. Ji leido surasti ir institucionalizuoti naujus valdymo reformavimo instrumentus ir technologijas. Deja, nemaža dalis pastangu reformuojant viešojo valdymo procesus nedavè lauktų rezultatų dẻl nepakankamos reformų politikos, t. y. reformavimo strateginių sprendimų ir programų kokybinių 
parametrų, arba vadinamojo reformų politikos dizaino tinkamumo. Iš dalies pasiteisino klasikinis teiginys, kad bet kuri viešoji politika dažniau neigyvendinama dèl to, kad jos formuotojai, strateginių krypčių modeliuotojai nepakankamai kokybiškai atlieka itin atsakingas politikos formavimo (kaip politikos fazès ir politikos procedūrų visumos) užduotis. Tai XX a. pabaigoje suponavo valdymo reformų modeliavimo, jų ịgyvendinimo procesų disfunkcijas, sukèlusias nemažą ekonominių ir socialinių visuomenès problemų. Todèl šiuolaikinio viešojo valdymo reformavimo procesas tampa žymiai kompleksiškesnis ir sudètingesnis, reikalaujantis geriausių tradicinio viešojo valdymo bei naujosios viešosios vadybos patirties, veiklos formų kūrybingo derinimo su postmoderniais iššūkiais viešajam valdymui, kurio reformavimo kryptys šiandien linksta nuo decentralizacijos orientacijų link centralizuoto valdymo krypčiu įtvirtinimo (bent jau Europos Sąjungoje). XX a. pabaigos reformų patirtis rodo, kad universalios ir radikalios reformos ne visada yra efektyvesnès nei atsargesnès modernizavimo kryptys, kokybiškai parengtos ir orientuotos ị vieną ar kitą regioną ar valstybinị darinį. Vienaip ar kitaip, tendencija valdymo bei mechanizmų konstrukcijų kūrimo procese naudoti griežtesnes valdymo, vadybos technologijas ir mechanizmus veda ị neovéberinių principų ir strateginių valdymo krypčių stiprejjimą šiuolaikinejje viešojo valdymo teorijoje ir praktikoje [3, p. 55].

\section{Išvados}

1. Šiuolaikinio viešojo valdymo modernizavimas turi tiek radikalių, tiek inkrementinių reformų praktikos patirtị. Abi bazinès valdymo reformų metodologijos turi tuos pačius tikslus - keisti ir tobulinti viešojo valdymo technologijas, vystyti inovatyvias ideologijas ir formuoti joms taikyti palankią organizacinę aplinką. Kadangi reformų esmès ir jų realizavimo kontekstualumas įvairiuose regionuose, reformas suponuojančios aplinkybès turi tiek bendras globalias priežastis, tiek specifines kiekvienos valstybės ar jų darinių patirtis, teoretikams ir valdymo praktikams itin svarbiais uždaviniais tampa būtinumas apibendrinti ịvairias viešojo valdymo modernizavimo reformų doktrinas, modelius, jų ideologinius pagrindus, konceptualizuoti reformų mechanizmų turinio ir formos charakteristikas.

2. Viešojo valdymo modernizavimo reformų praktikos kaip visuomenès sukauptų patirčių, žinių visumos panaudojimas yra dinamiškas, sistemingas arba permanentinis, t. y. reformų ciklų realizavimas nèra baigtinis reiškinys. Reformų dialektika suprantama tiesiogiai kaip nuolatinis procesas, kurio metu sukaupiamas patyrimas, kuris kartu tampa informacinès sklaidos objektu. Todèl valdymo reformų transformacija yra ne tik procesas, išplaukiantis iš globalizacijos suponuotų pokyčių, bet ir vykstantis visuose valdymo lygmenyse kartu su pokyčiais ir kartais (ne visada rezultatyviai) net aplenkiantis dar nepakankamai išryškèjusių pokyčiu būtinumą. Analizès požiūriu tokios situacijos yra įvardijamos kaip ex-post charakteristikos ir bruožus turinčios analitinès sintezès, interpretavimo ir prognostinès tyrimo ir analizès tradicijos. 
3. Remiantis modernaus valdymo indikatoriais ir reformų ịvairiuose regionuose praktika, galima teigti, kad valdymo reformų perspektyvos priklauso tiek nuo globalios visuomenès vystymosi sąlygų, tiek nuo regioninès ir subnacionalinès politinès, socialinès bei ekonominès organizacijų vidinès ir išorinès aplinkos specifikos. Viena aišku, kad XXI a. reformų kompleksiškumas ir toliau išlieka esmine dominante, determinuojančia ir viešojo valdymo sistemų reformavimo pobūdị. Kita reformų kryptis ir trajektorijoms ịtakos turinti dimensija yra susijusi su viešojo valdymo struktūrų gebejimais kūrybiškai panaudoti XX a. sukauptų ịvairių valdymo transformacijų patirtị ir teoriškai apibendrintą patirtị. Siekiant racionalaus politikos ir administravimo procesų turinio pokyčių, t. y. viešojo valdymo modernizavimo reformų efektyvumo, teoretikams ir valdymo praktikams būtina radikaliai keisti tradicines reformavimo procesų formas, orientuojant jas ị inovacinius reformavimo antecedentus tokiose tradicinės formos veiklose kaip reformų sprendimų rengimas, sisteminių reformų modeliavimas, biurokratinio valdymo ir demokratinio valdymo dualizmas, tarpsektorinè integracija, centralizavimo ir decentralizavimo dialektika.

\section{Literatūra}

1. Akintoje, A., Beck, M. Management and Finance of Public - Private Partnership. Oxford: Willey - Blackvel, 2009.

2. Bason, Ch. Leading Public Sector Innovation.Co - creating for a Better Society. Chicago: Policy Press, 2014.

3. Blum, J., Manning, N.Public Management Reforms acros OECD Countries. In T. Bovaird., E. Loffler. Public Management and Governance. London; Routledge, 2009.

4. Bovaird, T., Loffler, E. Public Management and Governance. London: Routledge, 2009.

5. Buškevičiūtè, J., Raipa, A. Sprendimai šiuolaikinio viešojo valdymo evoliucijoje. Viešoji politika ir administravimas, 2011, 10(1), 17-26.

6. Feiock, R., Jang, H. Non Profits as Local Government Service Contractors. Public Administration Review, 2009, Jully-August, p. 668-680.

7. Guzman, F., Sierra, V. Public - Private Collaborations: Branded Public Services? European Journal of Marketing, 2011, Vol. 46, No. 7, 1-32.

8. Hatch, M., Cunlife, A. Organization Theory. Modern Symbolic and Postmodern Perspectives. Oxford: University Press, 2006.

9. Isett, K. Networks in Public Administration Sholarship: Understanding Where We Are and Where We Need to Go. Journal of Public Administration Research and Theory, 2011,Vol. 21, No.1, 157-173.

10. Jenei, G. Transition and Transformation: The Last 20 Years and the Role of NISPAcee. In M. Vintar., A. Rosenbaum., G., Jenei., W. Drechler (eds.) The Past, Present and the Future of Public Administration in Central and Eastern Europe. Bratislava: NISPAcee Press, 2013.

11. Lane, J-E. State Management. London: Routledge, 2009.

12. Moliterno, T., Mahony, D. Network Theory of organization: A Multilevel Approach. Journal of Management, 2011, Vol. 37, No. 2, 443-467. 
13. Ongaro, E. Public Management Reform and Modernization. Cheltenham: MPG Books Group.

14. Pestoff, V., Brandsen, I. Governance and Third Sector. In St. Osborne (ed.). The New Public Governance. London: Routledge, 2010.

15. Pollitt, Ch., Bouckaert, G. Viešojo valdymo reforma. Vilnius: Algarvè, 2003.

16. Peters, B Guy. Meta - governance and Public Management. In. St. Osborne (ed.). The New Public Governance. London: Routledge. 2010.

17. Public Administration in a Global Context: IASIA AT 50. Dvivedi, O. (ed.). Bruxelles: Brulyant, 2011.

18. Raipa, A. Viešojo administravimo efektyvumo tūrinys. Viešojo administravimo efektyvumas (Red. A. Raipa). Kaunas: Technologija, 2007.

19. Raipa, A ir kiti. Modernus viešasis valdymas. Kaunas: Vitae Litera, 2012.

20. Wall, A. Public - Private Partnership in the USA. New York: Tailor and Francis, 2013.

Alvydas Raipa

\section{Trajectories and Tendencies of Public Governance Reform in the 21st Century}

Abstract

The analysis of public governance modernization and reform shows that public governance reform for each region and country has universality and specific features. Reform trajectories can be divided, described and explained as the trajectories of development methodology, mechanisms and instruments of ongoing reforms. The author, based on the opportunities of meta-analysis, classification and theoretic modeling methods, in the article seeks to indicate the essence of the main factors, trajectories and problems in the process of construction and implementation of public governance reform and modernization in the first decade of the 21st century. The aim of the article is to discuss and to show methodological aspects of the content of public governance reform and the impact of global change in a period of public governance evolution from the paradigm of the New Public Management to the New Public Governance. The author pays particular attention to the necessity to analyze and to explain the positions of theoretical constructs and to analyze the complexity of public governance reforms, as the modernization of bureaucratic form of governance, problems of centralization and decentralization, the creation of new innovative forms of inter-sector partnership, cross-sector interaction and the development of networking, hybrid organization as the modern form of creation of public value. Finally, the identification of content and complexity of public governance reform can help to define the main tendencies and trajectories, seeking to improve the quality of reform processes.

Alvydas Raipa - Mykolo Romerio universiteto Politkos ir vadybos fakulteto Viešojo administravimo instituto profesorius.

E. paštas alvydasraipa@mruni.eu

Alvydas Raipa, Doctor of Social Sciences, Mykolas Romeris University, Faculty of Politics and Management, Department of Public Administration, Professor.

E-mail: alvydasraipa@mruni.eu

Straipsnis įteiktas redakcijai 2014 m. rugsèjo mèn.; recenzuotas; parengtas spausdinti 2015 m. birželio mèn. 